\title{
VALIDATION OF A CFD MODEL FOR PREDICTION OF THE EFFICIENCY OF EVAPORATIVE COOLING IN POROUS PANELS
}

\section{VALIDACIÓN DE UN MODELO EN CFD PARA PREDECIR LA EFICIENCIA DE SISTEMAS DE ENFRIAMIENTO EVAPORATIVO EN PLACAS POROSAS}

\author{
Jairo Alexander Osorio Saraz ${ }^{1}$, Ilda de Fátima Ferreira Tinoco ${ }^{2}$, Keller Sullivan Oliveira Rocha ${ }^{3}$, \\ Marcio Arêdes Martins ${ }^{4}$, Flávio Alves Damasceno ${ }^{5}$
}

${ }^{1}$ Profesor - Universidad Nacional de Colombia - Sede Medellín, aosorio@unal.edu.co; ${ }^{2}$ Profesora - Universidad Federal de Vicosa - Brazil, tinoco@ufv.br; ${ }^{3}$ Ingeniero Agrícola, Ph.D. student - Universidad Federal de Viçosa - Brazil, kellersullivan@yahoo.com.br; 4Profesor - Universidad Federal de Vicosa - Brazil, aredes@ufv.br; ${ }^{5}$ Ingeniero Agrícola, Ph.D. student - Universidad Federal de Viçosa - Brazil, flavio.damasceno@ufv.br

Rev. U.D.CA Act. \& Div. Cient. 15(1): 209 - 217, 2012

\section{SUMMARY}

In regions with warm tropical and subtropical climates elevated air temperatures, especially during the dry seasons, can negatively affect thermal comfort inside installations used for animal and vegetative production, causing a significant decrease in production. An evaporative cooling system using non-saturated air to be introduced in the environment was employed, forcing air passage through different moist porous materials with the intention of thermal cooling, to improve the internal environment of these installations. However, difficulties in field experimentation have drastically limited the amount of information available regarding new porous materials that could possibly be used to substitute conventional material which is patented, expensive and with low durability. Therefore, the objective of the present study was to validate a computational model in Computational Fluid Dynamics (CFD) to predict cooling efficiency $(\eta)$ in moist porous pads construed of expanded clay. The numerical results obtained by the proposed model showed good correlation (81\%) with the experimental data, indicating its suitability to predict the behavior of these types of systems and for other porous material.

Key words: Computational Fluid Dynamics, porous media, expanded clay, animal production, green house

\section{RESUMEN}

En las regiones de climas tropicales y subtropicales cálidos, los altos valores de temperatura del aire, especialmente en épocas secas, pueden afectar negativamente el confort térmico dentro de los locales utilizados para la producción pecuaria y agrícola, dando lugar a una reducción significativa en su producción. Con el fin de promover la disminución de la temperatura en de las instalaciones y mejorar el ambiente interno de estas, se han utilizado los sistemas de resfriamiento evaporativo del aire que se introduce en el ambiente, abriéndose paso a través de diferentes placas porosas humedecidas. Sin embargo, dificultades en la experimentación práctica a limitado drásticamente informaciones relativas a nuevos materiales porosos posibles de ser empleados en sustitución al material convencional (Material celulósico) patentado, de elevado costo y de baja durabilidad. Debido a lo anterior, este estudio tuvo como objetivo validar un modelo computacional en dinámica de fluidos computacionales (CFD) para predecir la eficiencia del resfriamiento $(\eta)$ en placas porosas de arcilla expandidas humedecidas. Los resultados numéricos obtenidos por el modelo propuesto mostraron una buena correlación con los datos experimentales (81\%), lo que indica su aptitud para predecir el comportamiento de este tipo de sistemas, y de otros materiales porosos.

Palabras clave: Dinámica de Fluidos Computacional, medios porosos, arcilla expandida, producción animal, invernaderos.

\section{INTRODUCTION}

Brazilian aviculture has presented one of the greatest rates 
of technological and productivity development within the diverse segments of national animal protein production. This sector is one of the world's three largest (United States, China, and India) and stands out as the greatest exporter of chicken meat and is ranked fourth in world egg production (Boaretto, 2009).

In regions of warm tropical and subtropical climates, as in the case of Brazil, elevated air temperatures are detected among the main factors which negatively affect the activities of intensive animal and vegetable production (Tinôco et al. 2004; Vale et al., 2008; Silva et al. 2009).

Therefore, several forms of air cooling have been proposed for animal production installations, ranging from the optimized use of natural resources to artificial methods, such as forced ventilation associated with evaporative cooling systems (ECS). ECS in poultry installations can be obtained by means of misting (low and high pressure), or forced air ventilation over a moist porous material (pad system). According to Tinôco et al. (2004) and Carvalho et al. (2009), depending on the climatic conditions of the region where the evaporative cooling system is to be implemented, the dry bulb temperature can be reduced by up to $11^{\circ} \mathrm{C}$, being that in Brazil the average reduction is $6^{\circ} \mathrm{C}$.

In order to evaluate and compare moist porous pad evaporative cooling systems constructed of different materials, various studies have been performed (Moura \& Nääs, 1999; Tinôco et al. 2002, Tinôco et al. 2004; Gunhan et al. 2007). However, the difficulty of encountering a sufficient high number of similar installations in a single location along with the high costs of experimental implementation do not allow these studies to include a large number of variables and factors to be tested in the field.

Therefore, a possible solution to obtain better designs for efficiency optimization of a porous expanded clay pad may be obtained by means of computational simulations so that subsequent field testing only includes the treatments of interest.

Heat, mass and momentum transfer models, based on Computational Fluid Dynamics (CFD), allow for a reduction in the number of experiments and costs, as well as subsequent improvements in a given process after validation using experimental data. The application of CFD in the agricultural industry is quite recent, therefore, this technique is a highly viable alternative for evaluating the behavior of climatic variables inside both vegetation and animal structures (Norton et al. 2007; Osorio et al. 2009; Norton et al. 2009).
Computational Fluid Dynamics (CFD) model for predicting cooling efficiency with moist pads, constructed of expanded clay for use in animal production facilities or in greenhouses.

\section{MATERIAL AND METHODS}

For validation of the computational model, experimental data were collected at laboratories of the Universidade Federal de Lavras (UFLA), in the municipality of Lavras, Minas Gerais, Brazil, whose geographical coordinates are $21^{\circ} 14^{\prime} \mathrm{S}$ latitude and $45^{\circ} 00^{\prime}$ 'W longitude, with an elevation of $918 \mathrm{~m}$. The climate of the municipality, according to the Köppen classification, is type cwa, humid temperate with dry winters. The evaporative cooling system made use of a moist porous material (expanded clay) in pads with dimensions of $1.45 \times$ $1.56 \times 0.12 \mathrm{~m}$ (Figure $1 \mathrm{a}$ and $\mathrm{b}$ ).

Pre-programmed every minute, portable $\mathrm{HOBO}{ }^{\circledR}$ (United States, INC) loggers with accuracy of \pm 0.7 at $21^{\circ} \mathrm{C}$ were installed to measure air temperature $\left(t_{b s}\right)$ and relative humidity (UR) near the internal and external sides of the moist porous pad at intervals of two minutes. The loggers were housed inside a perforated PVC (diameter of 4 in) protective recipient to avoid damage to the equipment and readings were compared to those taken by an external sensor for verification of any interference of the recipient on the equipment readings. To quantify air flow through the moist porous pad, the sampling region was divided in nine equidistant points as shown in figure 1 . Air velocity was measured using a digital hot wire sensor (Testo 425), with measurement ranging between $0-20 \mathrm{~m} \mathrm{~s}^{-1}$ precision $\left({ }^{\circ} \mathrm{C}\right) \pm$ 0,5 , accuracy to $1 \%$ (pressure) and $2,5 \%\left(\mathrm{~m} \mathrm{~s}^{-1}\right)$ and $0,1^{\circ} \mathrm{C}$. Determination of air velocity adopted in the simulations was calculated as the product between the measured velocity of the air and the area of the pad.

Average temperature of the water applied to the pad was measured with a digital thermometer $\left( \pm 0.2^{\circ} \mathrm{C}\right)$ located within the reservoir and collecting data at every 30 minute intervals.

The cooling efficiency $(\eta)$ quantification for this type of system was calculated through according to equation 1 (ASHRAE, 1992), being dependent on the dry bulb and wet bulb temperature of the air before passing through the moist porous pad ( $T_{b s, i} ; T_{b u, i}$; respectively) and the dry bulb temperature after exiting the pad $\left(\mathrm{T}_{\mathrm{bs}, \mathrm{o}}\right)$.

$$
\eta=100 \frac{\left(T_{b s, i}-T_{b s, o}\right)}{\left(T_{b s, i}-T_{b u, i}\right)}
$$

The objective of the presented study was, therefore, to use a 
a)

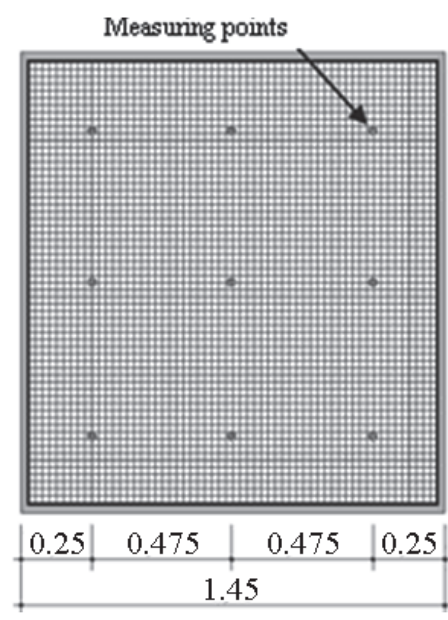

b)

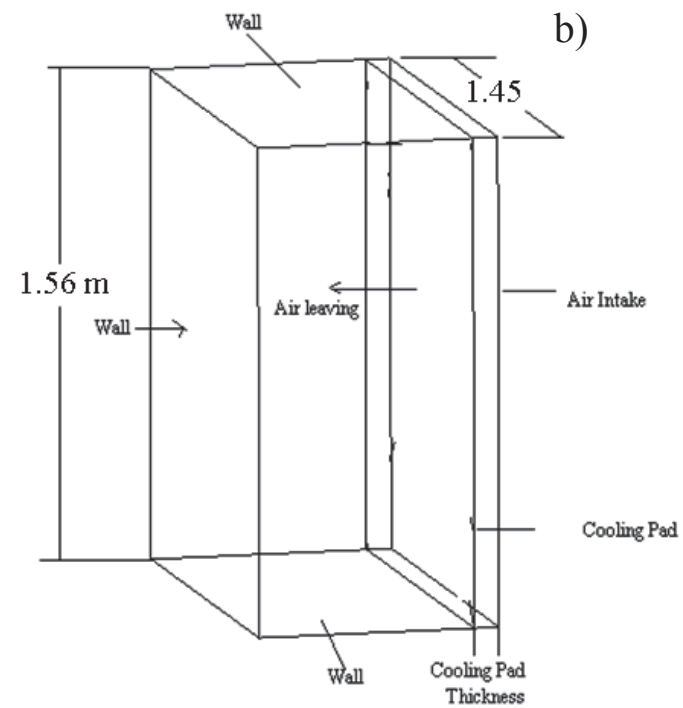

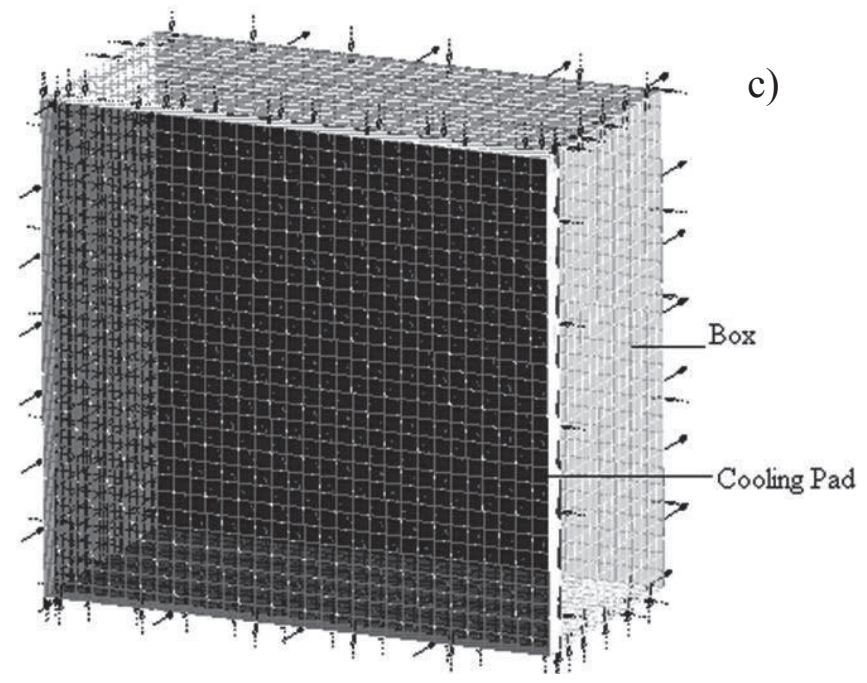

Figure 1. Porous pad: a) measuring points; b) schematic of pad inlets and outlets; c) Computational mesh

Physical characterization of the porous material: The porous material (expanded clay) with diameters between 22 and $32 \mathrm{~mm}$ was physically characterized in terms of specific mass, porosity, average diameter, average volume and surface area. Porosity of the utilized expanded clay was determined indirectly (equation 2 ) by filling the pores of a completely dry expanded clay sample with a fluid until completely saturating the sample. From the measured volumes of liquid and sample, total porosity was determined.

$\varepsilon_{p}=100 \frac{V}{V_{t}}$

Permeability of the porous material was obtained by equation
(3) where the constant referring to particle sphericity $\left(\mathrm{K}_{1}\right)$ has a value of 150 as obtained by Nield \& Bejan, (2006). The particle diameter $\left(D_{p}\right)$ was measurement directly in the materials:

$$
K=\frac{D_{p}{ }^{2}}{2 k_{1}} \frac{\varepsilon_{p}{ }^{3}}{\left(1-\varepsilon_{p}\right)^{2}}
$$

Mathematical Modeling: The ANSYS CFX software belongs to the Department of Agricultural and Environmental Engineering of the Federal University of Viçosa, and was employed to program and simulate the proposed method The initial step of all CFD works consists of defining the calculation domain, i.e., defining the geometry for which 
the numerical resolution of the equations describing the phenomena to be investigated is applied.

In this study, the CFD technique consisted of determining the average Reynolds number from the Navier - Stokes equations, discretizing the flow field, based on the finite volumes technique. The model which designates non-isothermal fluid flow is described by the continuity, momentum and energy equations, simplified as follows (Fluent, 2004; Ahmadi \& Hashemabadi, 2008).

In the air, the water mass diffusion coefficient (D) was obtained in tables from Incropera \& DeWitt (1999). This coefficient represents the speed at which water molecules are transported to the air and it is the main parameter that relates the diffusion mass flux of water to the air with the concentration gradient.

The term $\left(-\frac{d m}{d t} h_{f g}\right)$ in the equation of energy conservation (6) refers to a negative energy that is the defined as the latent heat of vaporization, multiplied by the water flow generated by the misting at a constant temperature. Thus, this term is coupled to the equation of energy and species conservation (7):

$\nabla \cdot(\rho U)=0$

$\nabla .(\rho U U)=\nabla p+\left[\mu_{\tau}\left(\nabla U+\nabla U^{T}\right]\right.$

$\nabla \cdot\left(-k \nabla T+\rho C_{p} T U\right)=-\frac{d m}{d t} h_{f g}$

$U \cdot \nabla C_{i}=\nabla \cdot\left(D \nabla C_{i}\right)+\frac{d m}{d t}$

Turbulent flow was modeled from the standard k- $\varepsilon$ model which evaluates viscosity $\left(\mu_{\tau}\right)$ from a relationship between turbulent kinetic energy $(\mathrm{k})$ and the dissipation of turbulent kinetic energy $(\varepsilon)$ (Launder \& Spalding, 1974).

$\mu_{\tau}=C_{\mu} \rho \frac{\kappa^{2}}{\varepsilon}$

Where the values of $k-\varepsilon$ are obtained by means of the equations:

$-\nabla \cdot\left[\left(\eta+\rho \frac{C_{\mu}}{\sigma_{\kappa}} \frac{\kappa^{2}}{\varepsilon}\right) \nabla \kappa\right]+\rho U . \nabla \kappa=\rho \frac{C_{\mu}}{\sigma_{\kappa}} \frac{\kappa^{2}}{\varepsilon}+\left(\nabla U+\nabla U^{T}\right)^{2}-\rho \varepsilon$

$-\nabla .\left[\left(\eta+\rho \frac{C_{\mu}}{\sigma_{\varepsilon}} \frac{\kappa^{2}}{\varepsilon}\right) \nabla \kappa\right]+\rho U . \nabla \varepsilon=\rho C_{s 1} C \mu \kappa+\left(\nabla U+\nabla U^{T}\right)^{2}-\rho C_{s 2} \frac{s^{2}}{\kappa}$

Dimensions and operating conditions of the porous pad model were used to generate the model in CFD. Therefore, the values measured in the experimental phase were managed as the boundary conditions of the computational model, which can be observed in Table 1 .

Results from the CFD model were verified and compared to those corresponding to the experimental measurements. Concordance between the measured values and those described by the CFD model were also evaluated by calculating the normal mean square error (NMSE) recommended by ASTM (2002). For this, a sample of 20 of the complete experimental datasets was used. Values with a NMSE less than 0.25 are accepted as good indicators of concordance and as this value approaches zero, the concordance between measured and predicted values is greater.

NMSE $=\frac{(\overline{C p-C o})^{2}}{(\text { Cpm Com })}$

Table 1. Boundary conditions and other media physical properties.

\begin{tabular}{|lc|}
\hline Inlet air velocity & $2.0 \mathrm{~m} \mathrm{~s}^{-1}$ \\
\hline External air temperature & $26^{\circ} \mathrm{C}$ \\
\hline Water temperature & $16^{\circ} \mathrm{C}$ \\
\hline Permeability of the expanded clay & $5.310^{-6} \mathrm{~m}^{-2}$ \\
\hline Porosity of the expanded clay & 0.68 \\
\hline Water flow rate & $0.008 \mathrm{~L} \mathrm{~s}^{-1}$ \\
\hline
\end{tabular}


$(\overline{C p-C o})^{2}=\frac{1}{n} \sum_{n}(C p i-C o i)^{2}$

Once validated, the model was used to analyze variation of pad efficiency for the porosities of 0.68 and 0.50 , thicknesses of 0.08 and $0.12 \mathrm{~cm}$ and velocities of $1.0,1.5$ and $2.0 \mathrm{~m}$ $\mathrm{s}^{-1}$, where these values are the most commonly encountered in practice for evaporative cooling systems using expanded clay, according to Vigoderis et al. (2007).

\section{RESULTS AND DISCUSSION}

A coarse mesh was used with 28725 nodes and 26970 quadratic elements, and after application of different refinement levels, a fine mesh with 30720 nodes and 35437 elements was employed. When considering the coarse and fine meshes, there is no significant difference in temperature values of the system, therefore greater refinement of this mesh was not necessary (Figure $1 \mathrm{C}$ ).

The encountered Reynolds number was $8.23 \times 10^{5}$, indicating that, as was expected, according to Vigoderis et al. (2007), the system presents turbulent flow within the porous plate.

The overall intention of this study was to determine average efficiency. This average was calculated for both the experimental data and proposed model for the entire cooling pad (Table 2), using the efficiency calculated for each point (nine points, Figure $1 \mathrm{a}$ ). This methodology was employed as recommended by Vigoderis et al. (2007).

Table 2. Comparison between experimental and modeled data for temperature and efficiency.

\begin{tabular}{|l|c|c|}
\hline \multirow{2}{*}{} & \multicolumn{2}{|c|}{ Temperature of air exiting the cooling pad $\left({ }^{\circ} \mathrm{C}\right)$} \\
\cline { 2 - 3 } & Experimental & Proposed model \\
\hline Average & 20.58 & 22.03 \\
\hline NMSE & \multicolumn{2}{|c|}{0.0009} \\
\hline
\end{tabular}

A comparison between the data generated from the developed model and experimental data showed that the average Tdb temperatures of air exiting the cooling pad did not significantly differ $(P<0.05)$ between the experimental values and those of the model. The comparison presented a normalized mean square error (NMSE) of 0.0009 for Tdb, indicating a good agreement between the results (Table 2). It was therefore concluded that the proposed model can be used to accurately predict the behavior of temperature at the outlet of the evaporative cooling pad constructed of expanded clay.

Figure 2 presents the efficiency of the porous pad when using porosities of 0.68 and 0.50 and thicknesses of 8 and $12 \mathrm{~cm}$, as a function of air intake velocity in the cooling pad. Such porosity range is commonly reported in literature for expanded clay particles. It was found that porosities between 0.5 and 0.68 did not significantly affect the efficiency of the pad. However, the pad thickness and air intake velocity do have an influence on efficiency.

Efficiencies for pad thicknesses of 8 and $12 \mathrm{~cm}$ and velocities between 1.0 and $2.0 \mathrm{~m} \mathrm{~s}^{-1}$ were in the range of $50-83 \%$ and $42-76 \%$, respectively. For velocities near $1.5 \mathrm{~m} \mathrm{~s}^{-1}$, Vigoderis et al. (2007) verified efficiency for a pad measuring nearly $8 \mathrm{~cm}$ thick was $77 \%$, while in this study an average efficiency of $70 \%$ was found. Differences may be due to the different climatic conditions in the surroundings where the

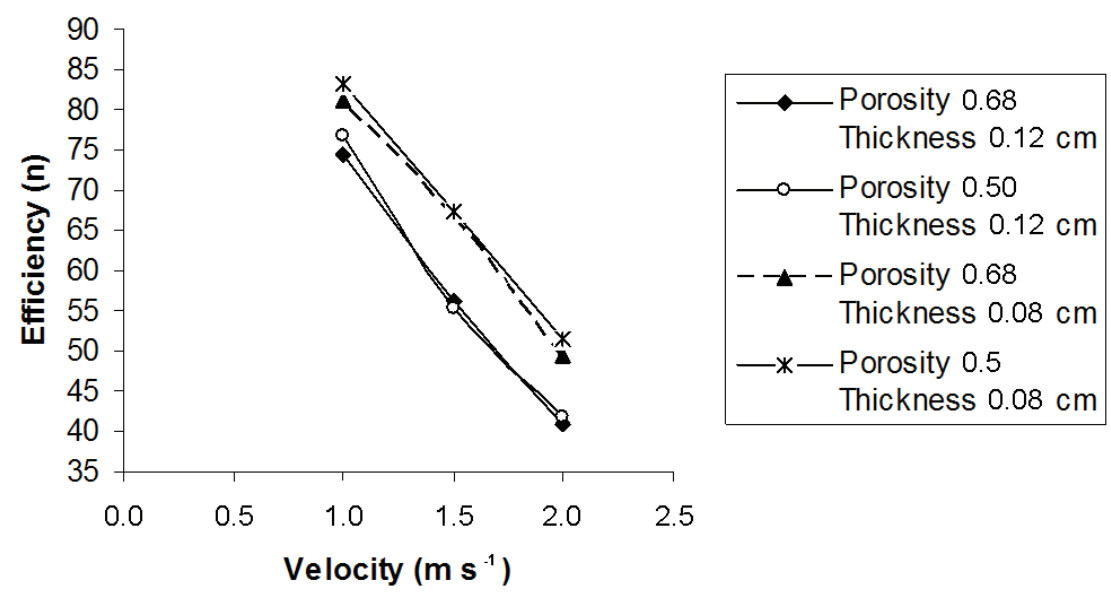

Figure 2. Efficiency of the pad $(\eta)$ as a function of media porosity and thickness at different air intake velocities. 


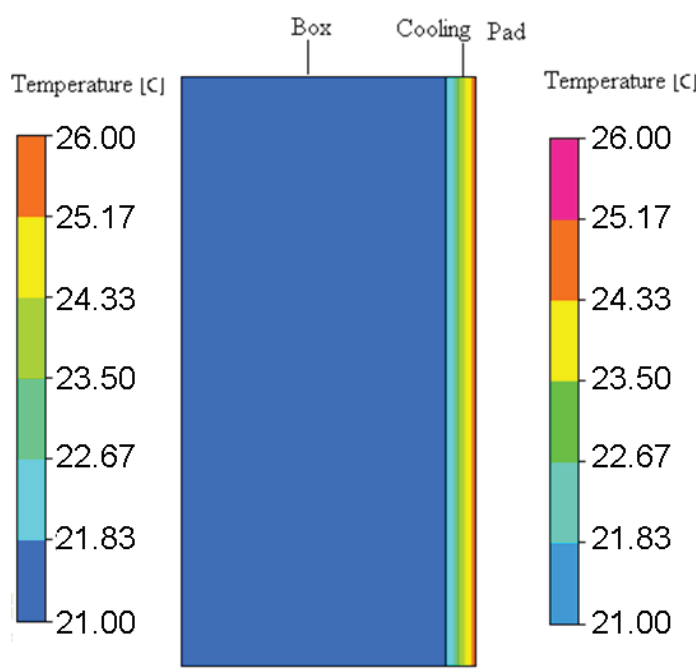

(a)

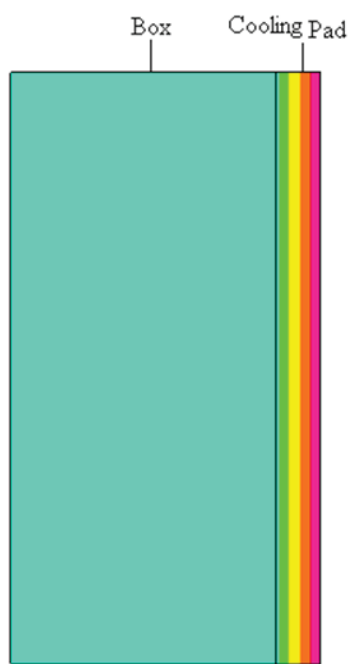

(b)

Figure 3. Spatial distribution of air temperature $\left({ }^{\circ} \mathrm{C}\right)$ : a) $0.08 \mathrm{~m}$ thick pad, (b) $0.12 \mathrm{~m}$ thick pad.

\begin{tabular}{|l|l|}
\hline \multicolumn{2}{|l|}{ Nomenclature } \\
\hline $\mathrm{C}_{\mathrm{p}}$ & Specific heat, $\mathrm{W} \mathrm{kg}^{-1} \mathrm{~K}^{-1}$ \\
\hline $\mathrm{C}_{\mathrm{pi}}$ & Predicted value \\
\hline $\mathrm{C}_{\mathrm{oi}}$ & Measured value \\
\hline $\mathrm{C}_{\mathrm{pm}}$ & Average predicted value \\
\hline $\mathrm{C}_{\mathrm{om}}$ & Average measured value \\
\hline $\mathrm{C}_{\mathrm{i}}$ & $\begin{array}{l}\text { Concentration of species } \mathrm{i} \\
\mathrm{D}\end{array}$ \\
\hline $\mathrm{D}_{\mathrm{p}}$ & Mass diffusion coefficient \\
\hline $\mathrm{h}$ & Particle diameter, $\mathrm{m}$ \\
\hline $\mathrm{h}_{\mathrm{fg}}$ & Convection heat transfer coefficient, $\mathrm{W} \mathrm{m}^{-2} \cdot \mathrm{K}^{-1}$ \\
\hline $\mathrm{k}$ & Thermal Conductivity, $\mathrm{W} \mathrm{m}^{-1} \cdot \mathrm{K}^{-1}$ \\
\hline $\mathrm{K}$ & Permeability, $\mathrm{m}^{-2}$ \\
\hline $\mathrm{k}_{1}$ & $\begin{array}{l}\text { Constant referring to particle sphericity with a value } \\
\text { of } 150\end{array}$ \\
\hline $\mathrm{m}_{\mathrm{p}}$ & Mass of the droplet, kg-1 \\
\hline $\mathrm{n}$ & Number of measurements \\
\hline $\mathrm{p}$ & Pressure, $\mathrm{N} \mathrm{m}^{-2}$ \\
\hline $\mathrm{T}$ & Temperature, $\mathrm{K}$ \\
\hline $\mathrm{U}$ & Mean velocity component, $\mathrm{m} \mathrm{s}^{-1}$ \\
\hline $\mathrm{V}$ & Pore volume, cm \\
\hline
\end{tabular}

\begin{tabular}{|c|l|}
\hline $\mathrm{V}_{\mathrm{t}}$ & Total volume of the recipient, $\mathrm{cm}^{3}$ \\
\hline Greek symbols \\
\hline$\rho$ & Density, $\mathrm{kg} \mathrm{m}^{-3}$ \\
\hline$\mu$ & Dynamic fluid viscosity, $\mathrm{kg} \mathrm{m}^{-1} \mathrm{~s}^{-1}$ \\
\hline$\kappa$ & Turbulent kinetic energy, $\mathrm{m}^{2} \mathrm{~s}^{-2}$ \\
\hline$\varepsilon$ & Dissipation of turbulent kinetic energy, $\mathrm{m}^{2} \mathrm{~s}^{-3}$ \\
\hline$\varepsilon_{\mathrm{p}}$ & Porosity of the material, $\%$ \\
\hline$\eta$ & Ratio between average flow and temporal scale \\
\hline Subscripts \\
\hline $\mathrm{t}$ & Turbulence \\
\hline Superscripts \\
\hline $\mathrm{T}$ & Transposition of the tensor \\
\hline Constants \\
\hline a,b & Constants equal to 2.9 and 0.75 \\
\hline $\mathrm{C}_{\mu}$ & 0.09 \\
\hline $\mathrm{C}_{\mathrm{s} 1}$ & 1.44 \\
\hline $\mathrm{C}_{\mathrm{s} 2}$ & 1.92 \\
\hline$\sigma_{\varepsilon}$ & 1.0 \\
\hline$\sigma_{\mathrm{\kappa}}$ & 1.3 \\
\hline
\end{tabular}


experiments were performed since results were found in a range between 70 and $80 \%$.

As it can be seen in figure 2, the pad with a thickness of $8 \mathrm{~cm}$ was more efficient than the $12 \mathrm{~cm}$ pad and the best operating conditions for inlet air velocity were 1.0 and $2.0 \mathrm{~m}$ $\mathrm{s}^{-1}$; however, the velocity of the air entering the pad depends on variables such as pad efficiency, the amount of heat that is supposed to be removed from the structure (either a poultry or greenhouse), maximum allowed air temperature within the installation, among others. In order to obtain optimum inlet air velocities, several ventilation rates may be tested through properly validated heat and mass transfer models such as those reported by Jain and Tiwari (2002), Kittas et al. (2003) and Ganguly \& Ghosh (2007) using the CFD tool.

The model indicated that system efficiency tended to be greater for thinner pads (Figure 2), since in our case the $8 \mathrm{~cm}(50-83 \%)$ thick pad exhibited higher efficiency than the $12 \mathrm{~cm}$ pad (42-76\%). This type of behavior was reported by Tinôco et al. (2004) and Vigoderis et al. (2007), who found that pads with thicknesses varying from 7.5 to $8.5 \mathrm{~cm}$ presented better results than those with thicknesses superior to $10 \mathrm{~cm}$ (range from $50-82 \%$ ). However, as the thickness of the porous material increases, resistance to air passage normally rises and, consequently, an increase in time in which air is in contact with the moist porous material occurs.

Figure 3 and 4 presents the temperature and velocity distribution across the porous pad and in the box for thicknesses of 8 and $12 \mathrm{~cm}$. When velocities are low the difference between the $\mathrm{T}_{\mathrm{db}, \mathrm{I}}$ and $\mathrm{T}_{\mathrm{bs}}$ tended to be higher, resulting in a larger temperature gradient $(\Delta T)$ and thus greater efficiency $(\eta)$. This happens when inlet air velocities are low and consequently greater heat transfer occurs between air and the bulk volume of the porous media, which is driven by the latent heat of vaporization, acquiring therefore a greater thermal equilibriums in the system, as also reported by Koca et al. (1991); Liao \& Chiu (2002) and Sapounas et al. (2008). It was found that velocity loss when using $8 \mathrm{~cm}$ thick pads with different inlet velocities (1.0, 1.5 and $2.0 \mathrm{~m} \mathrm{~s}^{-1}$ ) was approximately $30 \%$ throughout the pad. When utilizing the $12 \mathrm{~cm}$ thick pads, the velocity loss was $51 \%$, which resulted in a lower efficiency as compared to the use of the cooling pad of $8 \mathrm{~cm}$ to reach greater distances in livestock buildings.

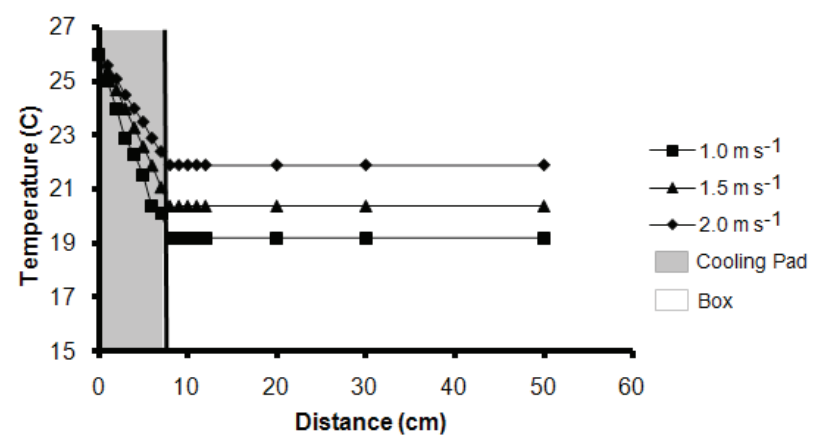

(a)

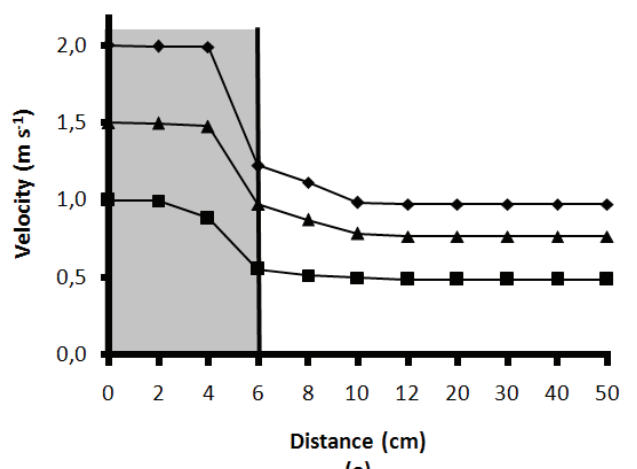

(a)

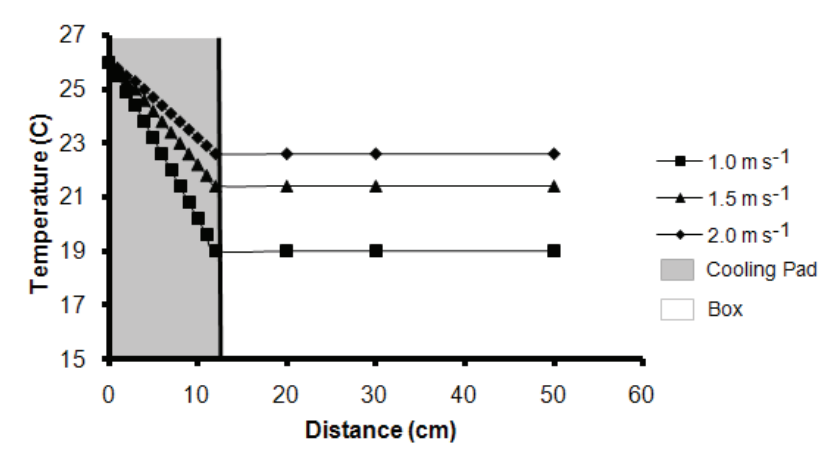

(b)

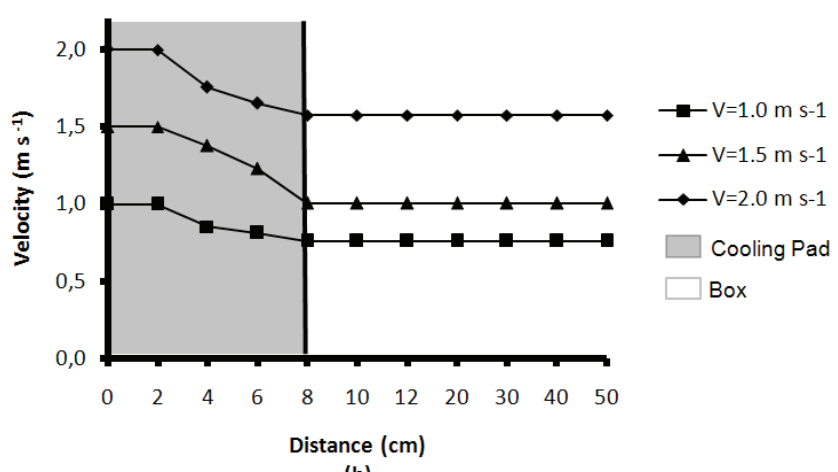

(b)

Figure 4. Temperature and velocity distribution of the air in function of distance for three velocities. a) $8 \mathrm{~cm}$ thick pads, b) $12 \mathrm{~cm}$ thick pads 
The following conclusions can be drawn of the results of this research:

The computational model implemented in CFD for the evaluation of evaporative cooling efficiency in systems with moist porous pads allows for simulation of different configurations such as variation in porosity, pad thickness and inlet air velocity, among others. The results from the developed model and the simulations may help in design of the system and subsequent selection of a porous material with purposed of improving the efficiency of evaporative cooling systems using cooling pads.

It was also found that pads with thicknesses of approximately $8 \mathrm{~cm}$ and velocities in the range of 1.0 to $1.5 \mathrm{~m} \mathrm{~s}^{-1}$ presented the best efficiencies for system cooling.

Acknowledgements: The authors would like to thank the Brazilian Government agencies FAPEMIG, the National Council of Technological and Scientific Development (CNPq - Brazil) and CAPES for their financial support, as well as the Federal University of Viçosa, Minas Gerais state, Brazil and the National University of Colombia at Medellin, Colombia. Conflicts of interests: The manuscript was presented and reviewed with the participation of all the authors who declare that there is no conflict of interest that threatens the validity of the results presented.

\section{BIBLIOGRAPHY}

1. AHMADI, A.H.; HASHEMABADI, S.H. 2008. 3D CFD simulation and experimental validation of particleto-fluid heat transfer in a randomly packed bed of cylindrical particles. Internal Com. Heat and Mass Transfer. 35(9):1183-1189

2. ASHRAE. EVAPORATIVE AIR COOLING, CH. 1992. In HVAC. Systems and Equipment Handdbook.: Am. Soc. of Heating, Refrigerating, and Air-Conditioning Engineers, Inc. Atlanta, Ga. 980p.

3. BOARETTO, N.T. 2009. Genetic improvement in broiler chicken. Rev. Formação e Informação em Zooctenia. 1(1):11-18.

4. ASTM. 2002. Guide for statistical evaluation of indoor air quality models (D5157-97). In: American Society for Testing Materials. ASTM Standards on Indoor Air quality, 2nd edition. West Conshohocken, Pa. p.6871.

5. CARVALHO, V.F.; YANAGI JUINIOR, T.; FERREIRA, L.; DAMASCENO, F.A.; SILVA, E.M.P. 2009. Mapping of potential use of evaporative cooling systems in Southeastern Brazil. Rev. Bras. Engenharia Agrícola e Ambiental. 13(3):358-366.

6. FLUENT. 2004 The manual of computational fluid dynamics (CFD), version 5.5. New Hampshire, USA. $625 p$.

7. GANGULY, A.; GHOSH, S. 2007. Modeling and analysis of a fan-pad ventilated floricultural greenhouse. Energy and Buildings. 39(10):1092-1097.

8. GUNHAN, T.; DEMIR, V.; YAGCIOGLU, A.K. 2007. Evaluation of the suitability of some local materials as cooling pads. Biosystems Eng. 96(3):369-377.

9. JAIN, D.E.G.; TIWARI, N. 2002. Modeling and optimal design of evaporative cooling system in controlled environment greenhouse. Energy Conversion and Management. 43(16):2235-2250.

10. KITTAS, C.; BARTZANAS, T.; JAFFRIN, A. 2003. Temperature gradients in a partially shaded large greenhouse equipped with evaporative cooling pads. Biosystems Eng. 85(1):87-94.

11. KOCA, R.W.; HUGHES, W.C.; CHRISTIANSON, L.L. 1991. Evaporative cooling pads: test, procedure and evaluation. Appl. Eng. Agric. 7(4):485-90.

12. LAUINDER, B.E.; SPALDING, D.B. 1974. The numerical computation of turbulent flows. Comput. Methods in Appl. Mech. \& Eng. 3(2):269-289.

13. LIAO, C.M., CHIU K.H. 2002 Wind tunnel modelling the system performance of alternative evaporative cooling pads in Taiwan Region. Building and Environ. 37(2):177-187.

14. MOURA, D.J.; NÄÄS, I.A. 1999. Evaluation of thermal efficiency in poultry houses shaded and ventilated artificially, in different orientations during the summer. Ver. Bras. Ciência Avícola. 1(1):167-174.

15. NIELD, D.A.; BEJAN, A. 2006. Convection in Porous Media. 3ed. New York: Springer. 640p.

16. NORTON, T.; GRANT, J.; FALLON, E.V.; SUN, D.W. 2009. Assessing the ventilation effectiveness of naturally ventilated livestock buildings under wind dominated conditions using computational fluid dynamics. Biosystems Eng. 103(1):78-99. 
17. NORTON, T.; SUN, D.W.; GRANT, J.; FALLON, E.V. 2007. Applications of computational fluid dynamics (CFD) in the modelling and design of ventilation systems in the agricultural industry: A review. Biores. Techn. 98(12):2386-2414.

18. OSORIO, S.J.A.; MARTINS, A.M.; TINÔCO, F.F.; DE PAULA, O.M.; SILVA, M.N.; ZAPATA, O.L. 2009. Uso de modelos com CFD para simular a distribuição da temperatura em aviários. In: X Congreso Argentino de Ingeniería Rural y II del MERCOSUR, 2009, Rosario. Anales del X Congreso Argentino de Ingeniería Rural y II del MERCOSUR.

19. SAPOUNAS, A.A.; NIKITA-MARTZOPOULOU, C.H.; BARTZANAS, T.; KITTAS, C. 2008. Fan and pad evaporative cooling system for greenhouses: evaluation of a numerical and analytical model. Acta Hort. (ISHS) 797(1):131-137.

20. SILVA, R.B.T.; NAAS, I.A.; MOURA, D.J.M. 2009. Broiler and swine production: animal welfare legislation scenario. Sci. Agr. 66(6):713-720.

21. TINÔCO, I.F.F.; FIGUIEIREDO, J.L.A.; SANTOS, R.C.; SILVA, J.N.; PUGLIESI, N.L. 2004. Porous pad used in evaporative cooling system. Rev. Eng. Agr. 12(1):17-23.

22. TINÔCO, I.F.F.; FIGUIEIREDO, J.L.A.; SANTOS, R.C; PAULA, M.O.; VIGODERIS, R.B.; PUGLISI, N.L. 2002. Evaluation of alternative materials used for pad making in the evaporative cooling system. Rev. Bras. Eng. Agr. Amb. 6(1):147-150.

23. VALE, M.M.; MOURA, D.J.M.; NAAS, I.A.; MEDEIROS, O.R.S.; RODRIGUES, A.L.H. 2008. Data mining to estimate broiler mortality when exposed to heat wave. Sci. Agr. 65(3):223-229.

24. VIGODERIS, R.B.; TINÔCO, I.F.F.; LACERDA FILHO, A.F.; SILVA, J.N. ; PAULI, D. G.; SILVA, C.E.; GUIMARÃES, M.C.C. 2007. Construction of a reduced-scale wind tunnel to evaluate expanded clay as pad material on evaporative air systems for thermal cooling of animal sheds. Eng. Agr. 15(3):191-199.

Received: 3 October 2011

Accepted: 30 March 2012 